\title{
CYCLICAL EFFECTS OF TRIIODOTHYRONINE ON BLOOD-FREE FATTY ACID AND GLUCOSE CONCENTRATIONS IN WARM-ADAPTED AND COLD-ADAPTED RATS
}

\author{
Akihiro Kuroshima, Katsuhiko DoI, and Masashi KuraHASHI \\ Department of Physiology, Asahikawa Medical College, Asahikawa
}

\begin{abstract}
Effects of triiodothyronine $\left(\mathrm{T}_{3}\right)(100 \mu \mathrm{g} / 100 \mathrm{~g}, \mathrm{sc})$ on blood-free fatty acid (FFA) and glucose concentrations were investigated in warmand cold-adapted rats. Blood specimens were obtained from the tail locally anesthetized with lidocaine. In warm-adapted rats FFA rose 3 to $6 \mathrm{hr}$ after administration of $\mathrm{T}_{3}$, but returned to the pre-injection level $12 \mathrm{hr}$ later. Thereafter, blood FFA level showed a repeated cyclical rise and fall every $12 \mathrm{hr}$ for up to $60 \mathrm{hr}$, while blood glucose level did not increase until $12 \mathrm{hr}$ later and this level was maintained for up to $36 \mathrm{hr}$. After that time it also showed a repeated rise and fall every $12 \mathrm{hr}$ for up to $60 \mathrm{hr}$. Both FFA and glucose levels returned to the initial values after $72 \mathrm{hr}$. Changes induced by $\mathrm{T}_{3}$ in blood levels of these metabolites were reciprocal. In cold-adapted rats the patterns of responses to $T_{3}$ were essentially the same as those observed in warm-adapted ones, except that $\mathrm{T}_{3}$ provoked a simultaneous rise in blood glucose as well as FFA $6 \mathrm{hr}$ after injection, although an extent of FFA increment was less than in warm-adapted rats. Reserpine pre-treatment caused a considerable reduction in the FFA mobilizing action of $T_{3}$. The FFA and glucose mobilizing action of $T_{3}$ was also observed at dosages of 25 and $6.25 \mu \mathrm{g} / 100 \mathrm{~g}$, although to lesser extent. These results indicated for the first time the cyclical action of $T_{3}$ on blood FFA and glucose concentrations, and a changed sensitivity to $T_{3}$ in coldadapted animals.
\end{abstract}

Thyroid hormones have been considered to be comparatively leisurely hormones, since a long latency is required before its physiological effects become evident. It has been reported that a measurable change in oxygen consumption requires about 20 to $30 \mathrm{hr}$ after a single administration of triiodothyronine $\left(\mathrm{T}_{3}\right)$ in the thyroidectomized rats during which time no appreciable increase in the basal metabolism occurs and the maximal effect is seen about $70 \mathrm{hr}$ later (TATA et al.,

Received for publication September 20, 1974

黒島晨沉，土居勝彦，倉橋昌司 
1963). Recently, however, physiological actions of thyroid hormones other than an elevation of energy metabolism have been demonstrated in the earlier stages after the injection of thyroid hormones (Guz et al., 1961; НосH and МоттA, 1968; Myant and Witney, 1967; Rich et al., 1959; Silverman et al., 1972; TATA et al., 1963; Volfin et al., 1969), among which a rise in blood-free fatty acid (FFA) concentration would be worthwhile considering. Because such a rise in blood FFA level might mediate a stimulatory effect of thyroid hormones on the oxygen consumption of the whole organism (MYANT and WITNEY, 1967; Rich et al., 1959; SILVERMAN et al., 1972). It is the purpose of this study to characterize further the mode of $\mathrm{T}_{3}$ action on blood FFA and glucose in warm-adapted rats as well as cold-adapted ones.

\section{MATERIALS AND METHODS}

Male rats of the Wistar strain were used. The animals were divided into two groups, the warm-adapted group was housed at $25^{\circ} \mathrm{C}$ and the cold-adapted one was kept at $5^{\circ} \mathrm{C}$ for 4 to 5 weeks in order to allow adaptation to cold. They were placed under illumination from 5.00 to $18.00 \mathrm{~h}$ and were given standard rat biscuits (Oriental MF) and tap water ad libitum. The average body weight of warmadapted rats was $339 \mathrm{~g}$ and of cold-adapted ones $295 \mathrm{~g}$ during the experiment.

The rats were injected with 3, 5, 3'-triiodothyronine sodium salt (Tokyo Kasei Kogyo Ltd.), dissolved in $0.1 \mathrm{~N} \mathrm{NaOH}$ and diluted to an appropriate concentration with saline before the experiment, sc at $9.00 \mathrm{~h}$. Control animals received the vehicle only. The rats kept at $5^{\circ} \mathrm{C}$ were transferred into the $25^{\circ} \mathrm{C}$ room $24 \mathrm{hr}$ prior to $\mathrm{T}_{3}$ injection. All the animals were used in the fed state.

The blood specimens were obtained at a certain time intervals after a single injection of $\mathrm{T}_{3}$ from the cut end of the tail which had been locally anesthetized with $1 \%$ lidocaine solution $20 \mathrm{~min}$ prior to the blood sampling. Each experimental group consisted of 5 to 8 animals. This method of blood collection proved to be valid for the purpose of obtaining blood successively from the small animals such as rat under physiological conditions because anesthesia with urethane or pentobarbital, or stress stimuli such as tail cutting without local anesthesia; were found in our laboratory to significantly influence blood FFA as well as glucose level (unpublished data). Blood volume obtained at one time was $0.3 \mathrm{ml}$. Glucose in $0.1 \mathrm{ml}$ blood was determined by the method of RoE (1955). FFA in $0.2 \mathrm{ml} \mathrm{blood}$ was measured by the method of ITAYA and UI (1965).

The student's $t$ test was used in all statistical comparisons.

\section{RESULTS}

$T_{3}$ effects in warm-adapted rats

Figure 1 showed the changes in the concentrations of FFA and glucose after 
the injection of $100 \mu \mathrm{g} / 100 \mathrm{~g}$ of $\mathrm{T}_{3}$ or the vehicle as control. Control rats injected with the vehicle only did not show any appreciable variations in the blood compositions throughout the experimental period up to $96 \mathrm{hr}$. On the other hand, in $\mathrm{T}_{3}$ injected rats the blood level of FFA rose markedly as early as $6 \mathrm{hr}$ after the injection. The extent of increment at this time was $199.7 \%$ of the preinjection level. However, by $12 \mathrm{hr}$ after the injection it returned to the preinjection level. After that, interestingly, the blood FFA level repeatedly rose and fell every $12 \mathrm{hr}$ up to $60 \mathrm{hr}$ after the injection. The peak value was already observed after $6 \mathrm{hr}$ during the first rise. In a separate series of experiment we examined an earlier action of $\mathrm{T}_{3}$ in blood FFA level by obtaining the blood $0,1,3$, and $6 \mathrm{hr}$ after the injection (Table 1). Evidence of the elevating action of $T_{3}$ on blood FFA level was significant as early as $3 \mathrm{hr}$ after the injection, although its extent was much less than that at $6 \mathrm{hr}(p<0.02)$.

Blood glucose level showed a significant elevation $12 \mathrm{hr}$ after $\mathrm{T}_{3}$ injection, later than the rise of blood FFA level (Fig. 1). A maximal increment of $22.0 \%$ was observed $36 \mathrm{hr}$ after the injection. It was interesting to note that the blood glucose
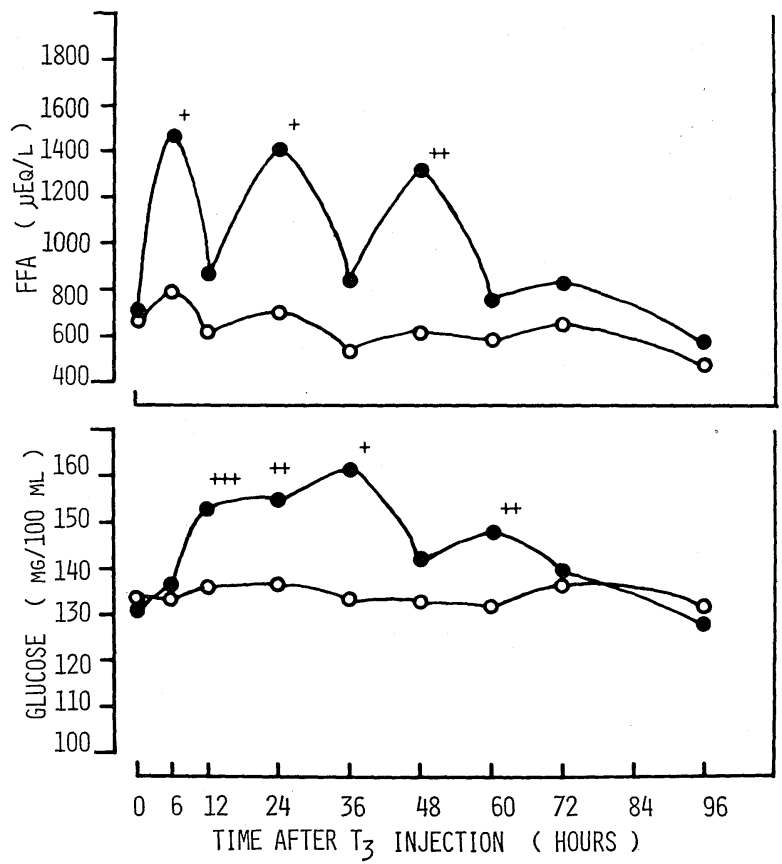

Fig. 1. Effects of $T_{3}$ on blood FFA and glucose concentrations in warm-adapted rats. Rats were injected with $100 \mu \mathrm{g} / 100 \mathrm{~g}$ of $3,5,3^{\prime}$-L-triiodo-thyronine sodium salt/0.1 ml $0.01 \mathrm{~N}$ $\mathrm{NaOH} / 100 \mathrm{~g} \mathrm{sc}$ at $9.00 \mathrm{am}$.

$\bigcirc$ : Vehicle control group. $\bullet: \mathrm{T}_{3}$-injected group. $+: P<0.001 \mathrm{vs} 0 \mathrm{hr}$ level. ++ : $P<0.01$ vs $0 \mathrm{hr}$ level. $+++: P<0.05$ vs $0 \mathrm{hr}$ level. Values without marks indicate that they are not significantly different from $0 \mathrm{hr}$ levels. Each point represents the mean value for 5 to 6 animals. 
Table 1. Effect of reserpine on FFA mobilizing action of $\mathrm{T}_{3}$.

\begin{tabular}{|c|c|c|c|c|c|}
\hline \multirow[b]{2}{*}{$\begin{array}{l}\text { Hours after } \\
\mathrm{T}_{3} \text { injection }\end{array}$} & \multicolumn{5}{|c|}{ Blood FFA concentration ( $\mu \mathrm{Eq} /$ liter $)$} \\
\hline & 0 & 1 & 3 & 6 & 24 \\
\hline $\begin{array}{l}\text { Non- } \\
\text { reserpinized } \\
\text { vehicle } \\
\text { control group } \\
(6) \\
\text { Non- } \\
\text { reserpinized } \\
\mathrm{T}_{3} \text { Group (5) }\end{array}$ & $358 \pm 27.0$ & $424 \pm 18.8^{\mathrm{a}}$ & $460 \pm 39.3^{a}$ & $544 \pm 82.6^{\mathrm{a}}$ & $523 \pm 11.1^{b}$ \\
\hline $\begin{array}{l}\text { Reserpinized } \\
\text { vehicle } \\
\text { control group } \\
\text { (8) } \\
\text { Reserpinized }\end{array}$ & $441 \pm 26.2^{g}$ & - & - & $476 \pm 53.8^{\mathrm{a}}$ & $453 \pm 22.3^{\mathrm{a}}$ \\
\hline $\mathrm{T}_{3}$ group $(7)$ & $419 \pm 35.7^{g}$ & - & - & $662 \pm 80.2^{\mathrm{d}, \mathrm{h}}$ & $915 \pm 67.3^{b, i}$ \\
\hline
\end{tabular}

Results are expressed as means \pm standard errors. Number in the parentheses indicates the number of animals.

a : not significant vs $0 \mathrm{hr}$ level, ${ }^{\mathrm{b}}: P<0.001$ vs $0 \mathrm{hr}$ level, ${ }^{\mathrm{c}}: P<0.01$ vs $0 \mathrm{hr}$ level, ${ }^{\mathrm{d}}: P<0.02$ vs $0 \mathrm{hr}$ level, e: $P<0.05$ vs 0 hr level, f: $P<0.001$ vs Non-reserpinized vehicle control group, $\mathrm{g}$ : not significant $v s$ corresponding non-reserpinized group, ${ }^{\mathrm{h}}: P<0.001$ vs non-reserpinized $\mathrm{T}_{3}$ group, ${ }^{\mathrm{i}}: P<0.05$ vs non-reserpinized $\mathrm{T}_{3}$ group.

level also showed repeated rise and fall every $12 \mathrm{hr}$ for up to $60 \mathrm{hr}$ after the injection with the exception of an elevated level at $24 \mathrm{hr}$. Further, the changes in these two energy yielding substrate levels were found to be reciprocal; the rise of FFA coincided with the fall of glucose.

The effects of $T_{3}$ on the blood FFA and glucose levels completely disappeared at $72 \mathrm{hr}$ after the injection.

\section{$T_{3}$ effects in cold-adapted rats}

The elevating effects of $T_{3}$ on blood FFA and glucose concentrations were also examined in cold-adapted animals, in order to study changes in sensitivity, if any, to this thermogenic hormone in cold-adapted animals. The results are shown in Fig. 2. The patterns of changes in the blood FFA and glucose concentrations were essentially the same as those observed in warm-adapted rats, that is, oscillatory variations in the concentrations of the blood substrates and reciprocal relationship between FFA and glucose were shown. However, at an earlier stage, $6 \mathrm{hr}$ after $\mathrm{T}_{3}$ administration the extent of increase in blood FFA was significantly smaller $(p<0.05)$ in cold-adapted rats $(128 \pm 4.4 \%$ of preinjection level $)$ than in warm-adapted ones $(215 \pm 32.6 \%$ of preinjection level $)$ as can be seen in Fig. 2 .

Blood glucose level rose significantly as early as $6 \mathrm{hr}$ after the injection, while no significant change was seen in warm-adapted animals at this time.

With exception of these two points mentioned above, there was no appreciable difference in the variations of blood FFA and glucose levels. 


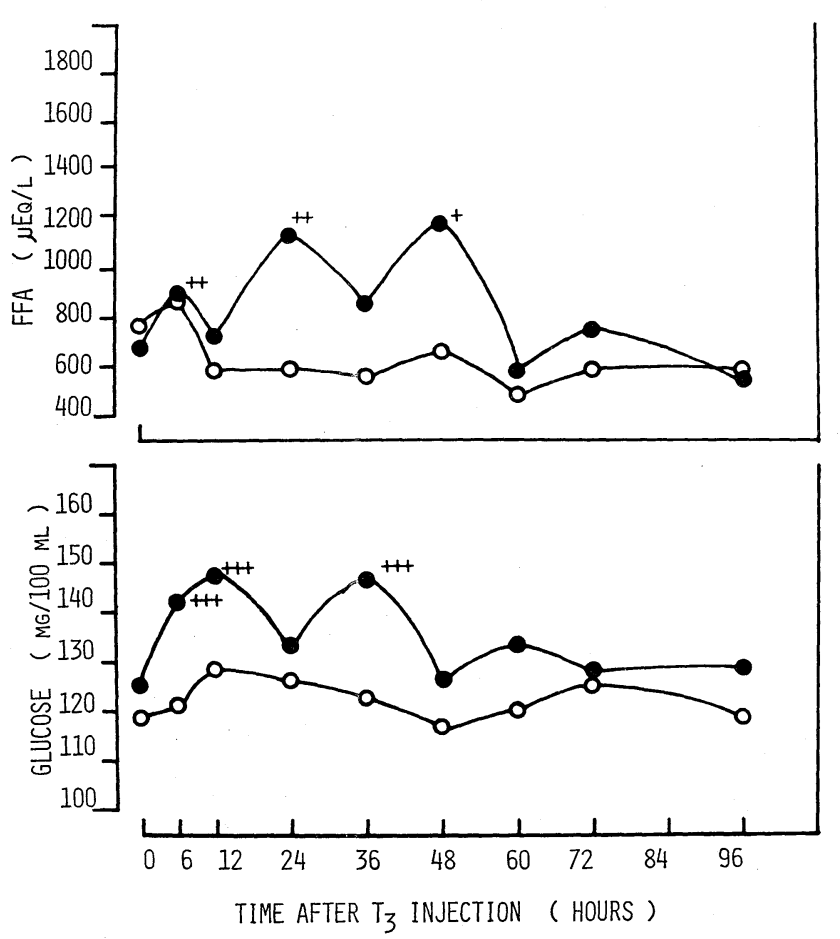

Fig. 2. Effects of $T_{3}$ on blood FFA and glucose concentrations in cold-adapted rats. Legends same as in Fig. 1.

\section{Effect of reserpine on $T_{3}$ action}

The lipolytic effect of catecholamines has been indicated to be dependent upon and potentiated by the presence of thyroid hormones (FAIN, 1973). Therefore, the FFA elevating action of $T_{3}$ observed in the present study might be exerted by $T_{3}$ potentiation of adipokinetic action of catecholamines. Accordingly, a possible involvement of catecholamines in $\mathrm{T}_{3}$ action was examined in the reserpinized rats, which were injected with $1 \mathrm{mg} / \mathrm{kg}$ of reserpine sc $18 \mathrm{hr}$ prior to the $\mathrm{T}_{3}(100 \mu \mathrm{g} / 100 \mathrm{~g})$ injection. This dose of reserpine has been found to produce a considerable depletion of catecholamines in adipose tissue (PAolettr et al., 1961). As shown in Table 1, reserpinization did not abolish FFA mobilizing action of $T_{3}$, although an increment in blood FFA was considerably smaller in the reserpinized rats.

Dose-response relationship of $T_{3}$ effects

Dose-dependency of $T_{3}$ action in doses of $6.25,25$, and $100 \mu \mathrm{g} / 100 \mathrm{~g}$ was studied. The results are shown in terms of percent changes in Table 2. In this series of experiment oscillatory variations in blood FFA and glucose concentrations after $\mathrm{T}_{3}$ were again confirmed; blood FFA level was elevated at 6 and $24 \mathrm{hr}$, while blood glucose level in a dose of $100 \mu \mathrm{g} / 100 \mathrm{~g}$ of $\mathrm{T}_{3}$ was elevated at 12 and $24 \mathrm{hr}$. 


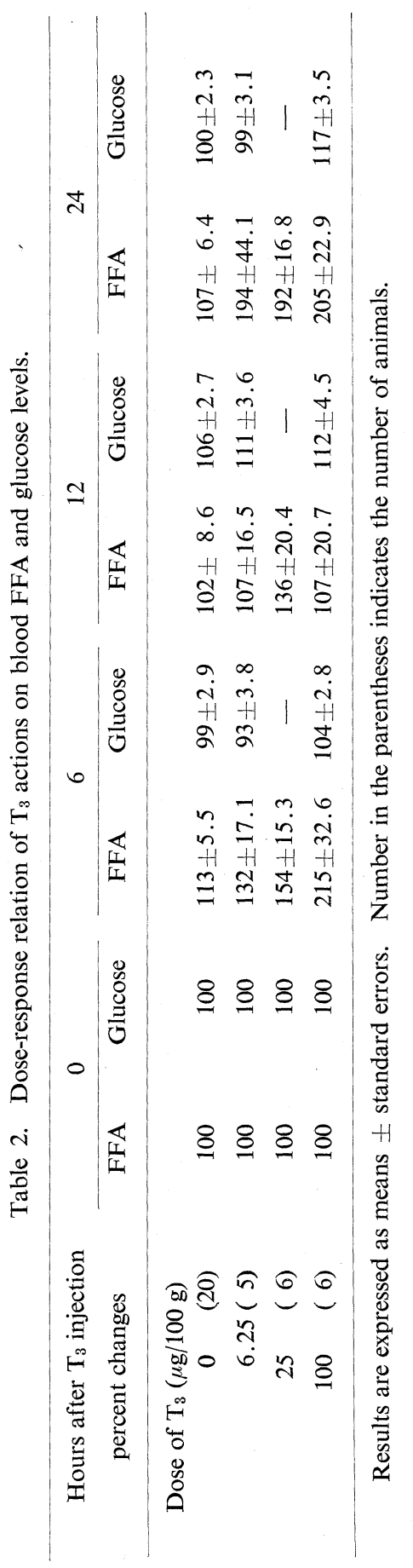


In blood FFA level a dose-response relation at $6 \mathrm{hr}$ was observed, but at $24 \mathrm{hr}$ almost similar responses were produced within the range of dosages adopted in the present study. As to blood glucose level, its level was similarly increased in a dose of $6.25 \mu \mathrm{g} / 100 \mathrm{~g}$ at $12 \mathrm{hr}$, while a subsequent rise at $24 \mathrm{hr}$ which was observed in a dose of $100 \mu \mathrm{g} / 100 \mathrm{~g}$ was abolished in a dose of $6.25 \mu \mathrm{g} / 100 \mathrm{~g}$.

\section{DISCUSSION}

The present study reveals for the first time a unique oscillatory and cyclical action of $T_{3}$ on blood FFA and glucose concentrations. It should be noted that such a specific mode of hormonal action has not been described previously for thyroid hormones or other hormones. The physiological significance of this phenomenon remains to be elucidated. However, a stimulating effect of $T_{3}$ on mobilization of energy yielding substrates preceding an increased metabolism might be one of key steps leading to hypermetabolism due to $T_{3}$. A reciprocal relation between blood FFA and glucose levels might be explained by the glucose-FFA cycle hypothesis (JENKINS, 1967) in order to utilize these substrates efficiently.

With regard to the underlying mechanism the action of $T_{3}$ on blood FFA level might be partly dependent on catecholamine stimulation, since reserpinization brought about a considerable reduction in FFA mobilizing effect of $\mathrm{T}_{3}$. However, the present result could not exclude a possibility completely that a lipolytic action of $T_{3}$ is controlled by a mechanism independent of catecholamine secretion. In this context, it has been reported that reserpine did not totally abolish the elevations of plasma FFA levels by exercise (TAYLOR, 1972) or stress stimuli such as immobilization or electrical stimulation (Nikulcheva and Ryzhenkov, 1973). Furthermore, thyroxine has been found to be necessary for the development of maximum sensitivity to noradrenaline in rats, whereas noradrenaline is not necessary for the maximum effect of thyroxine on oxygen consumption (VILLEMAIRE and LEBLANC, 1968).

A circadian periodicity in various endocrine activities has been well documented (Wurtman, 1967). As to the pituitary-thyroid axis, LePPäluoto et al. (1974) have recently reported that the serum immunoassayable thyrotropin concentration exhibited the highest value at $11.00 \mathrm{~h}$ and lowest one at $19.00 \mathrm{~h}$ in the rat. It is especially interesting to refer to the experiment by DUNN and LIN (1974), indicating the daily fluctuations in adrenal catecholamine concentration, the high value of norepinephrine during the afternoon and that of epinephrine during the late evening and early morning hours. Therefore, it is conceivable that $T_{3}$ might exert its cyclical effect by potentiating the metabolic actions of catecholamines which would be periodically secreted. However, this notion could not explain the reciprocal relation between blood FFA and glucose concentrations in $T_{3}$ action, inasmuch as catecholamines are known to elevate blood FFA and glucose levels concurrently (Himms-HAGEN, 1967). Thus, the physiological significance of the 
circadian rhythm of endocrine activities in the cyclical effect of $T_{3}$ revealed in the present study is not readily apparent and the mechanism(s) responsible for the cyclical effect of $\mathrm{T}_{3}$ on blood metabolites appears amenable to further investigations.

It is of interest to note the less increase in blood FFA level and greater increase in blood glucose level at an early stage $6 \mathrm{hr}$ after $T_{3}$ injection in cold-adapted rats as compared with the responses in warm-adapted animals. This result might reflect a changed sensitivity to metabolic action of $T_{3}$ in the peripheral tissues of cold-adapted rats. It has been believed that an activity of thyroid gland is of primary importance in the control of thermogenesis in cold adaptation. Recent studies, however, would appear to favor a very minor participation of thyroid hormone, thyroxine, in cold adaptation (CHAFFEE and RoBERTS, 1971). On the other hand, ReICHLIN et al. (1973) proposed that $\mathrm{T}_{3}$ would be substantially important for cold adaptation, since plasma thyroxine level was slightly but significantly low in cold-adapted rats, whereas plasma $T_{3}$ level was significantly higher in these animals than in warm-adapted ones. The present results suggest a change in the metabolic sensitivity to thyroid hormone due to cold adaptation and such modification might be related to an increased non-shivering thermogenesis during cold adaptation. Previous works suggest an elevated gluconeogenesis as well as glucose turnover (DEPOCAS and MASIRONI, 1960) and increased utilization of FFA (MASORO, 1966) in cold-adapted animals. Recently, Kuroshima et al. (1974) reported that cold-adapted rats exhibited a greater rise in blood glucose level and a less rise in blood FFA level in response to acute cold exposure. Their results are compatible with the present findings in cold-adapted rats after $T_{3}$ injection. Therefore, greater rise in blood glucose level and less rise in blood FFA in response to either cold exposure or $\mathrm{T}_{3}$ might reflect an increased gluconeogenesis and an accelerated FFA utilization in cold-adapted animals.

\section{REFERENCES}

Chaffee, R. R. J. and Roberts, J. C. (1971) Temperature acclimation in birds and mammals. Ann. Rev. Physiol., 33: 155-240.

Depocas, F. and Masironi, R. (1960) Body glucose as fuel for thermogenesis in the white rat exposed to cold. Am. J. Physiol., 199: 1051-1055.

DunN, J. D. and LIN, F.-J. (1974) Daily fluctuations in adrenal catecholamine concentration. Experientia, 30: 348-349.

FAIN, J. N. (1973) Biochemical aspects of drug and hormone action on adipose tissue. Pharmacol. Rev., 25: 67-118.

Guz, A., Kurland, G, S., and FreedberG, A. S. (1961) Heart rate and $\mathrm{O}_{2}$ consumption after triiodothyronine in the myxedematous rabbit. Am. J. Physiol., 200: 58-60.

Himms-Hagen, J. (1967) Sympathetic regulation of metabolism. Pharmacol. Rev., 19: 367-461.

Hoch, F. L. and MоттA, M. V. (1968) Reversal of early thyroid hormone action on mitochondria by bovine serum albumin in vitro. Proc. Natl. Acad. Sci., 59: 118-122.

ITAYA, K. and UI, M. (1965) Colorimetric determination of free fatty acids in biological fluids. J. Lipid Res., 6: 16-20.

JENKIns, D. J. A. (1967) Modern concepts of free-fatty acid and blood glucose homeostasis in 
disease involving altered lipid metabolism. Lancet, II: 341-344.

Kuroshima, A., Kurahashi, M., Doi, K., Ohno, T., and Fujta, I. (1974) Effect of cold adaptation and high-fat diet on cold resistance and metabolic responses to acute cold exposure in rats. Jap. J. Physiol., 24: 277-292.

Leppäluoto, J., RANTA, T., and Tuomisto, J. (1974) Diurnal variation of serum immunoassayable thyrotropin (TSH) concentration in the rat. Acta Physiol. Scand., 90: 699-702.

Masoro, E. J. (1966) Effect of cold on metabolic use of lipids. Physiol. Rev., 46: 67-101.

Myant, N. B. and Witney, S. (1967) The time course of the effect of thyroid hormones upon basal oxygen consumption and plasma concentration of free fatty acid in rats. J. Physiol., 190: $221-228$.

Nikulcheva, N. G. and Ryzhenkov, V. E. (1973) Effect of reserpine on FFA mobilization caused by extreme stimulation of animals. Pharmacology, 9: 217-225.

Paoletti, S., Smith, R. E., Maickel, R. P., and Brodie, B. B. (1961) Identification and physiological role of norepinephrine in adipose tissue. Biochem. Biophys. Res. Commun., 5: 424429.

Reichlin, S., Bollinger, J., NeJad, I., and Sullivan, P. (1973) Tissue thyroid hormone concentration of rat and man determined by radioimmunoassay: biological significance. Mt. Sinai J. Med., 40: 502-510.

Rich, C., Bierman, E. L., and Schwartz, I. L. (1959) Plasma nonesterified fatty acids in hyperthyroid states. J. Clin. Invest., 38: 275-278.

Roe, J. H. (1955) The determination of sugar in blood and spinal fluid with anthrone reagent. J. Biol. Chem., 212: 335-343.

Silverman, L. H., BeznAK, M., and Kako, K. J. (1972) Effect of reserpine and triiodothyronine on myocardial lipoprotein lipase, metabolic rate and plasma free fatty acids in rats. Arch. Int. Pharmacodyn., 199: 68-375.

Tata, J. R., Ernster, L., Lindberg, O., Arrhenius, E., Pedersen, S., and Hedman, R. (1963) The action of thyroid hormones at the cell level. Biochem. J., 86: 408-428.

TAYLOR, A. W. (1972) Free fatty acid levels in exercised and nonexercised reserpinized rats. Am. J. Physiol., 223: 319-322.

Villemaire, A. and LeBlanc, J. (1968) Interaction thyroïde-noradrénaline sur le métabolisme. J. Physiol. (Paris), 60 (Suppl. 1): 381.

Volfin, P., KAPLAY, S. S., and SANAdI, D. R. (1969) Early effect of thyroxine in vivo on rapidly labeled mitochondrial protein fraction and respiratory control. J. Biol. Chem., 244: 56315635.

WUrtman, R. J. (1967) Effects of light and visual stimuli on endocrine function. In Neuroendocrinology, Vol. II, ed. by Martini, L. and Ganong, W. F. Academic Press, New York, pp. 19-59. 